\title{
Michael Adams: new life member of the International Committee on Taxonomy of Viruses (ICTV)
}

\author{
Arcady R. Mushegian ${ }^{1}$ (D) Andrew J. Davison ${ }^{2}$ (i)
}

Received: 15 April 2019 / Accepted: 23 April 2019 / Published online: 31 May 2019

(c) This is a U.S. Government work and not under copyright protection in the US; foreign copyright protection may apply 2019

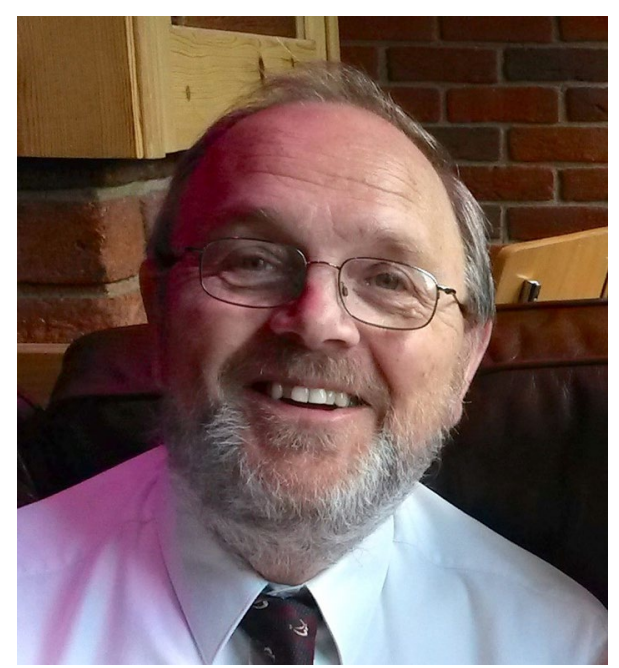

We are pleased to announce that Dr Michael J Adams has been elected as a Life Member, following nomination by the President, recommendation by the Executive Committee, and ratification by the ICTV membership. Mike obtained his degrees at the University of Oxford and Imperial College London, and was a plant pathologist at Rothamsted Research (Harpenden, UK) from 1973 until his retirement from that post in 2006. The later phase of his research was on the epidemiology and control of soil-borne cereal viruses and

Handling Editor: Sead Sabanadzovic.

Arcady R. Mushegian

mushegian2@gmail.com

Andrew J. Davison

andrew.davison@glasgow.ac.uk

1 Division of Molecular and Cellular Biosciences, National Science Foundation, 2415 Eisenhower Avenue, Alexandria, VA 22314, USA

2 MRC-University of Glasgow Centre for Virus Research, Sir Michael Stoker Building, 464 Bearsden Road, Glasgow G61 1QH, UK their vector Polymyxa graminis, with particular reference to barley yellow mosaic virus and barley mild mosaic virus.

Mike became involved in the work of the ICTV in 2001 as a member of the Potyviridae Study Group, a position that he held for 16 years. He joined the Executive Committee as chair of the Plant Virus Subcommittee in 2005. He then took on the important role of ICTV Business Secretary from 2011 until 2017, at that point standing down to enjoy proper retirement. He served for a total of 14 years as chair of the Flexiviridae Study Group (2003-2011) and the Virgaviridae Study Group (2011-2017), and co-edited the Ninth Report of the ICTV published in 2011. Mike's great efficiency, broad grasp of taxonomic issues, good humour and, most of all, constant wisdom, were greatly appreciated by his colleagues on the Executive Committee.

Life membership is an honorary appointment bestowed in recognition of outstanding service to virus taxonomy. Life members have voting rights in ratifying taxonomic proposals, when changes to the ICTV Statutes or Rules are proposed, and in elections to the Executive Committee. Information on Life Members is available at the ICTV web site (https://www.ictvonline.org).

Publisher's Note Springer Nature remains neutral with regard to jurisdictional claims in published maps and institutional affiliations. 